\title{
Burner Design for biogas-fuelled Stirling engine for electric power generation
}

\author{
${\text { Ardiyansyah } \text { Yatim }^{1, *}, \text { Ade Luthfi }}^{1}$, and Raden Chemilo ${ }^{1}$ \\ ${ }^{1}$ Mechanical Engineering Department, Faculty of Engineering, Universitas Indonesia, Kampus UI Depok 16424, Indonesia
}

\begin{abstract}
The Stirling engine is an external combustion where the fuel combustion process takes place outside the cylinder, at the combustion chamber or burner. Stirling engine offers flexibility of fuel used for the power generation hence is a potential substitute to fossil fuelled internal combustion engine and contribute toward more sustainable power generation. In this study a burner for Gamma V2-6 Stirling engine is designed and developed for a biogas-fuelled power generation system. The heat used to power the Stirling engine is obtained from combustion of biogas at the burner. The system has $5 \mathrm{~kW}$ capacity fuelled by $165 \mathrm{~kg} /$ day solid waste (biowaste) from local farm. The bio-digester needed is $20 \mathrm{~m}^{3}$. The combustion temperature of the burner is in the range of 600 to $1000{ }^{\circ} \mathrm{C}$. The required fuel input is $60,000 \mathrm{BTU} / \mathrm{hr}$ or equivalent to $17 \mathrm{~kW}$. The system requires constant heat from the combustion chamber hence a specific burner is designed to fulfil the purpose and accommodate biogas composition and optimum heat transfer to the engine. The burner is able to provide for simultaneous air preheater for lower fuel consumption leading to $37 \%$ lower fuel consumption.
\end{abstract}

\section{Introduction}

Demand for energy in form of electricity is increasing continuously and is rising even in higher rate in 2017 [1]. Generally, energy sources that have been used to generate the electricity mostly come from fossil fuels, such as coal, petroleum, natural gas and others. Fossil fuels are an energy resource whose formation takes millions of years and can be said to be non-renewable energy or known as conventional energy sources. Fossil energy use has caused an increase in greenhouse gases due to the release of carbon dioxide to the atmosphere. Increased concentration of greenhouse gases is one of the causes of global warming. Therefore, alternative energy sources are needed to reduced greenhouse gases with renewable heat sources. In developing an ecofriendly electricity generation system, particular attention must be considered to increase the efficiency of the system and reducing the greenhouse gas emissions. Natural gas and steam turbine usually installed in large scale electricity generation. While at small scales industries and communities, smaller capacity of electricity generations is needed.

Currently there are a lot of increased uses of biogas as a renewable fuel especially for small scales industries or communities. One of the reasons is the availability of the biogas because it can be easily taken from livestock manure owned by small communities.

The composition of the gas generally consists of methane $\left(\mathrm{CH}_{4}\right)$ with a composition of $55 \%$ and carbon dioxide $\left(\mathrm{CO}_{2}\right)$ with a composition of $45 \%$. Methane gas as the main constituent of biogas is the second largest contributor to the greenhouse effect after $\mathrm{CO}_{2}$ [2]. The way to reduce the greenhouse effect from biogas is to burn the biogas for heating or as a generator fuel so that the compound becomes $\mathrm{CO}_{2}$ or $\mathrm{CO}$.

Biogas is taken from animal waste, especially cattle. The availability of cattle ranching is not a problem for the small community, which is common for generally has farms. Processing livestock manure such as cattle into biogas by using a tool called biodigester. In biodigester, animal waste is fermented to produce biogas in the reaction tank. In this study a biodigester which has been used in Kemakmuran area, Depok, Indonesia is used as the source of fuel for the power generation.

The produced biogas can then be used for heating for gas stoves as has been done by the people in the area or it can be used as fuel for electricity generation. The Stirling engine is one of the electricity generation engines which are using the external combustion process and compatible with biogas as a fuel.

The Stirling engine is a machine that uses the Stirling principle in the energy generation process. This machine is an external combustion engine because the fuel combustion process takes place outside the engine. The Stirling engine is used because the technology is environmentally friendly [3-8].

The Stirling engine used in this study is a Gamma Stirling V2-6 engine with $446 \mathrm{~cm}^{3}$ displacement volume and peak power generation of up to $10 \mathrm{~kW}$. The required fuel input is $60,000 \mathrm{BTU} / \mathrm{hr}$ or equivalent to $17 \mathrm{~kW}$. It is required to provide a stable fuel combustion heat and

\footnotetext{
Corresponding author: ardiyansyah@eng.ui.ac.id
} 
according to Stirling engine's specifications so that good electrification occurs.

The combustion chambers can be divided into two types according to the mixing way of air and natural gas: one type is the diffusion combustion chamber and the other type is the pre-mixing combustion chamber. Even though the diffusion combustion chamber incorporates a relatively simple structure and low cost, the flame is so long that it might eventually overheating the heater tubes of Stirling engine. Additionally, the second wind is required to make sure the combustion process is often nearly completed. Thus it is difficult to manage the temperature around the wall of heater tubes. If the combustion chamber is fully premixing structure, the combustion potency is higher and therefore the flame can be shorter, however, the manufacturing price should be higher because of the complex design of the premixing structure, and the temperature around the wall of heater tubes is not easy to be controlled. The study strives to design a burner and a combustion chamber for Stirling engine which uses biogas as a fuel source.

\section{Biogas fuelled Stirling engine}

\subsection{Stirling engine}

Stirling engine offers several advantages compared to diesel and petroleum engines, e.g.: it is an external combustion engine, thermally regenerative, simple in construction, virtually quiet, safe in operation and flexible to adopt any heat sources such as solar, biomass, geothermal energy, or even an industrial waste. Stirling engine had wide applications, working conditions and performance of earlier stages [9].

The Stirling engine can be classified based on the configuration of the hot and cold space into three types i.e. alpha, beta and gamma. A comprehensive review of the three types of the Stirling engine is presented by Cheng and Yang [9].

Components of the Stirling engine are based on the Stirling brothers' design in 1840 [10] as shown in Figure 1. In this design, the regenerator and cooler are still separated from the Stirling engine. The main components are:

\section{- Power Piston}

The piston power serves to transmit the power created by the pressure to the engine crankshaft. The piston is made quite tight with a cylinder so that it can maintain the pressure difference for the Stirling engine.

\section{- Displacer}

Displacer moves the working fluid inside the cylinder. The displacer function traps the working fluid so that it is between hot space and cold space. The displacer is made loose against the cylinder so that it allows gas flow between the displacers. Displacer must be light and have low thermal conductivity to avoid heat flow from the working fluid to the displacer.

- Heat Exchanger

Heat Exchanger functions to transfer heat from and into the Stirling engine. In Figure 1, there are two heat exchangers which are to heat the gas and to cool it.

\section{- Regenerator}

Regenerator functions a temporary heat storage element so that the difference in temperature between hot space and cold space is maintained. Regenerators require low flow friction properties, high thermal capacity, but low thermal conductivity. Usually used metal wire mesh.

- Working Fluid

Working fluid as a substance that meets the Stirling engine and moves in a closed cycle. Working fluids which have low type density, high heat capacity, and high constant gas values.

Many technical challenges are encountered when manufacturing Stirling machines [7, 9-12], which include the following: the various configurations of Stirling engines represents a barrier against technology spread, regenerator characteristics have the greatest impact on engine performances, working gas leakage is a major difficulty when engine operates under high pressure, optimum rotation speed must be respected to ensure the machine proper functioning.

\subsection{Biogas fuel}

Biogas is produced from biomass and organic wastes from sewage sludge anaerobic digestion, commercial composting, landfills, biomass gasification, animal farm manure anaerobic co-digestion with energy crops, agrofood industry digestion facilities which resulted in methane-rich gas mixture. The utilization of biogas can be performed directly or through purification process [13].

Biogas consists of various kinds of gas compounds. The main content of biogas is methane $\left(\mathrm{CH}_{4}\right)$ and carbon dioxide $\left(\mathrm{CO}_{2}\right)$. In addition, there are other compounds in biogas such as carbon monoxide (CO) and hydrogen sulphide $\left(\mathrm{H}_{2} \mathrm{~S}\right)$. Table 1 describes the percentage of volume-based biogas composition with various raw materials based on experiments from Ukpai and Nnabuchi in 2012 [8].

Table 1. Biogas composition by \% volume.

\begin{tabular}{|c|c|c|c|c|}
\hline $\begin{array}{c}\text { Raw } \\
\text { Material }\end{array}$ & $\mathrm{CO}_{2}$ & $\mathrm{H}_{2} \mathrm{~S}$ & $\mathrm{CO}$ & $\mathrm{CH}_{4}$ \\
\hline Cow dung & 27.2 & 0.1 & 4.7 & 67.9 \\
\hline Cowpea & 33.2 & 0.5 & 10.1 & 56.2 \\
\hline $\begin{array}{c}\text { Cassava } \\
\text { peeling }\end{array}$ & 32.2 & 3.1 & 13.3 & 51.4 \\
\hline
\end{tabular}

The biogas composition is influenced by biogas raw materials, a mixture of biogas raw materials with water, mixed temperature, and acidity. For example in the above experiment, the ratio of the mass of a mixture of cow dung and water is 1: 2 with a mixture temperature of $36^{\circ} \mathrm{C}$.

The nature of biogas which is important in its function as fuel is the value of the heating value or calorific value. In biogas, this value is entirely 
determined by the percentage of methane gas content. The heating value of methane gas at $68^{\circ} \mathrm{F}$ and 14.7 psia are obtained as follows [14], the Higher Heating Value $(\mathrm{HHV})=23,890 \mathrm{BTU} / \mathrm{lb}$ or $994.7 \mathrm{BTU} / \mathrm{ft}^{3}$ and the Lower Heating Value $(\mathrm{LHV})=21,518 \mathrm{BTU} / \mathrm{lb}$ or 896.0 BTU / $\mathrm{ft}^{3}$ in under standard conditions, namely temperature $32^{\circ} \mathrm{F}$ and pressure of $1 \mathrm{~atm}$. The LHV value of dry biogas is determined below in table 2. The utilization of biogas varies from direct burning for cooking, heating and lighting to power generation through various combustion engine types.

Table 2. Biogas composition by \% volume [14]

\begin{tabular}{|c|c|c|c|c|c|}
\hline \multirow{2}{*}{$\begin{array}{l}\% \mathrm{CH}_{4} \\
\text { by volume }\end{array}$} & \multirow{2}{*}{$\mathrm{g} \mathrm{mol} \mathrm{wt}$} & \multirow{2}{*}{$\begin{array}{l}\mathrm{CH}_{4} \text { Percent } \\
\text { by weight }\end{array}$} & \multicolumn{2}{|c|}{ Density } & \multirow{2}{*}{$\begin{array}{l}\mathrm{LHV} \\
\text { Btu/ft' } \\
\end{array}$} \\
\hline & & & lbs d.g. ${ }^{*} / \mathrm{ft}^{3}$ & $\mathrm{ft}^{3} / \mathrm{lb}$ d.g. & \\
\hline $40 \%$ & 32.8 & $19.6 \%$ & 0.0916 & 10.92 & 385 \\
\hline $42 \%$ & 32.3 & $20.9 \%$ & 0.0900 & 11.11 & 405 \\
\hline $44 \%$ & 31.7 & $22.3 \%$ & 0.0885 & 11.30 & 424 \\
\hline $46 \%$ & 31.1 & $23.7 \%$ & 0.0869 & 11.50 & 443 \\
\hline $48 \%$ & 30.6 & $25.2 \%$ & 0.0854 & 11.71 & 463 \\
\hline $50 \%$ & 30.0 & $26.7 \%$ & 0.0838 & 11.93 & 482 \\
\hline $52 \%$ & 29.5 & $28.3 \%$ & 0.0822 & 12.16 & 501 \\
\hline $54 \%$ & 28.9 & $30.0 \%$ & 0.0807 & 12.39 & 520 \\
\hline $56 \%$ & 28.4 & $31.7 \%$ & 0.0791 & 12.64 & 540 \\
\hline $58 \%$ & 27.8 & $33.5 \%$ & 0.0776 & 12.89 & 559 \\
\hline $60 \%$ & 27.2 & $35.4 \%$ & 0.0760 & 13.16 & 578 \\
\hline $62 \%$ & 26.7 & $37.3 \%$ & 0.0744 & 13.43 & 598 \\
\hline $64 \%$ & 26.1 & $39.3 \%$ & 0.0729 & 13.72 & 617 \\
\hline $66 \%$ & 25.6 & $41.4 \%$ & 0.0713 & 14.02 & 636 \\
\hline $68 \%$ & 25.0 & $43.7 \%$ & 0.0698 & 14.34 & 655 \\
\hline $70 \%$ & 24.4 & $46.0 \%$ & 0.0682 & 14.66 & 675 \\
\hline * dry gas & & & & & \\
\hline
\end{tabular}

\subsection{Biogas combustion}

For relatively small scale such as residential, municipal or community application, the biogas fuel offers competitive advantage compared to fossil fuel. Its characteristics as fuel obtained from waste makes it costs to nothing to obtain. Furthermore, despite its lower calorific value compared to natural gas, biogas generation can be applied almost anywhere.

As the concentration of carbon dioxide in biogas is relatively higher (compared to natural gas and liquefied petroleum gas), specific combustion equipment, or a burner is needed, if removal process of it is not feasible or requires complex equipments. Mordaunt and Pierce [15] presented in details the effects of carbon dioxide doping concentration in methane mixed gas to simulate the biogas combustion.

The combustion chamber configuration is presented in Figure 1[15]. The present of carbon dioxide increases the carbon monoxide formation and weakens the flame. Another requirement is the prevention of condensation of hydrogen sulphide or water contained in biogas fuel. This can be achieved by controlling the temperature inside the combustion chamber higher than the condensation point temperature of the gases [16].

Several studies [17-19] presented the effects of these gases along with inlet temperature and distance, air and fuel mixing configuration to the biogas combustion performance.

Direct use of biogas fuel for Stirling engine power generation without removal of $\mathrm{CO}_{2}$ and other non-

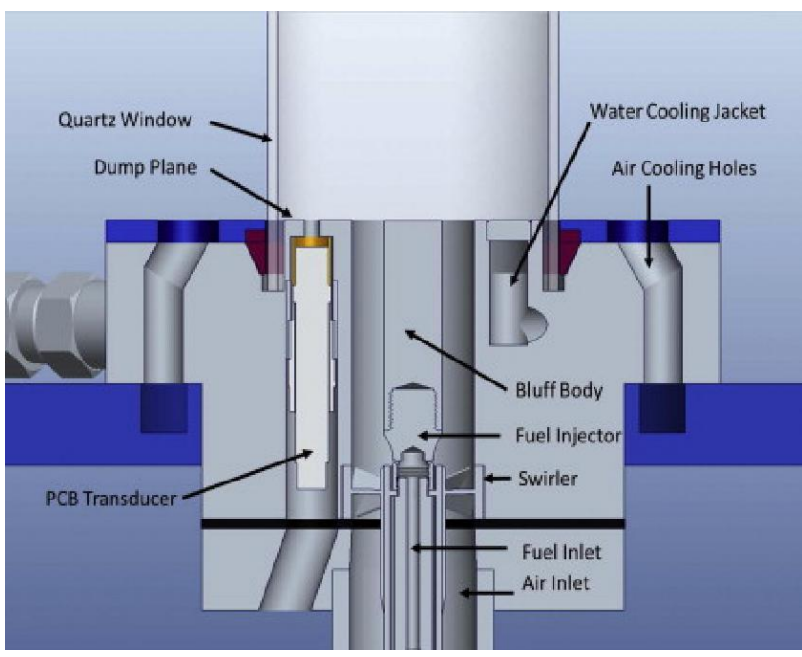

Fig. 1. Configuration of combustion chamber for biogas combustion suggested by Mordaunt and Pierce [15]

combustible gases require the combustion chamber or burner to be able to have preheat air injection.

The preheat air at elevated temperature cause the mean temperature inside the burner, leading to decrease of fuel consumption of the combustion process. The effect of preheat air temperature on the fuel consumption is numerically simulated and presented in Figure 2 by Hosseini et al. [20]

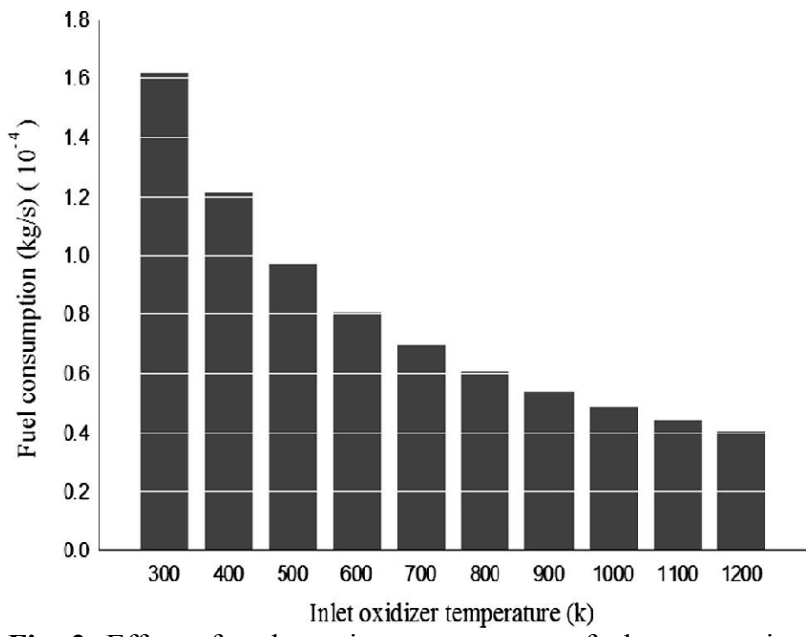

Fig. 2. Effect of preheat air temperature on fuel consumption by Hosseini et al. [20]

As important as air inlet temperature, the utilization of biogas fuel through combustion process directly can also be improved by the air velocity entering the combustion chamber. For this reason, combustion chamber configuration design is critical for biogas combustion. Multiple circumferential air inlet around a single, central biogas fuel inlet is suggested by [1] as depicted in Figure 1. Another approach is presented, whereof high velocity jet air inlet at the central of the chamber is surrounded by several low velocity biogas fuel [21]. 


\section{Experimental setup}

The power generation system is built nearby the buried biodigester at the local farm. Biogas is generated from the biowaste of around 50 cows. For every 30 cows, the produced biowaste is about $10 \mathrm{~kg}$ per cow per day with estimated electric power equivalent of $33 \mathrm{kWh}$.

The biodigester is of a fixed-dome type. The accumulated biogas is continuously directed to outside of the biodigester. The biodigester is shown in Figure 3. At peak session, the capacity of the biogas resulted up to $1,0001 /$ day. The biogas is then directed and burned at the combustion chamber of the Stirling engine. In the Stirling engine, the combustion chamber is the most important component, because the performance of the Stirling engine is depends on the performance of the combustion inside the combustion chamber.

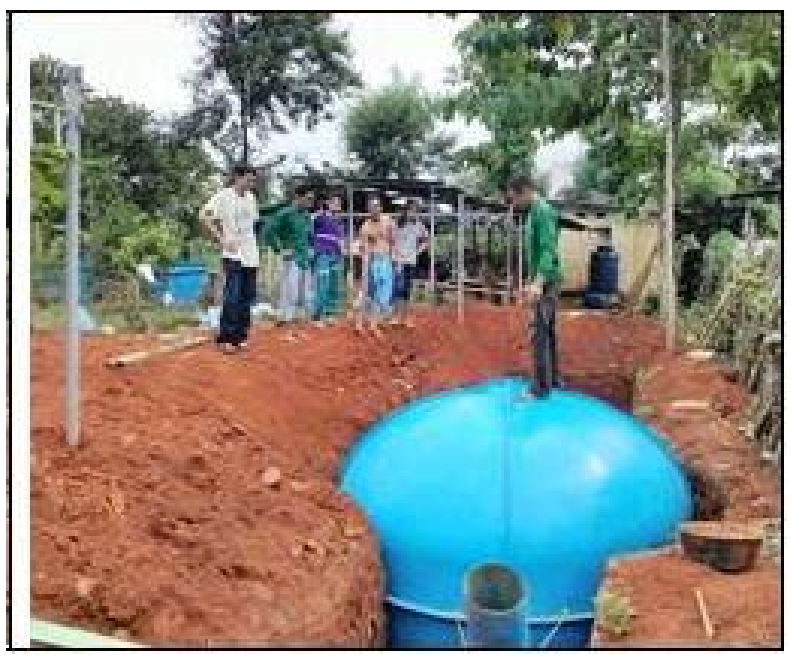

Fig. 3. Biodigester used in the present experiment at local farm in Depok, Indonesia

The combustion chamber that is designed for Stirling engine consists of three main parts; burner, heat exchanger cavity, and heater tube of Stirling engine. The combustion process only happens in burner. The fuel and fresh air are mixed prior to being ignited inside the burner. The design the structure of combustion chamber for Stirling engine is shown in Figure 4. The burner assembled on the top of heat exchange cavity, and heater tubes of Stirling engine are installed at the bottom of heat exchanger cavity. There is also air preheating layer in heat exchange cavity. The burner includes a fuel connection tube and igniter which is used to ignite biogas mixed with fresh air.

Air inlet configuration is designed to allow for preheating process by the initial biogas burning and is showed in Figure 5. The air is directed to inlet by a blower and goes through a space between the combustion chamber and outer shell (indicated with blue arrow in Figure 5). While flowing through the space, the air is heated by hot wall of the combustion chamber. A biogas fuel inlet line is located at the central of the combustion chamber. The mixing of the hot air and fuel (orange arrow) cause the combustion of the biogas fuel and the heat is then rejected to the Stirling engine heat

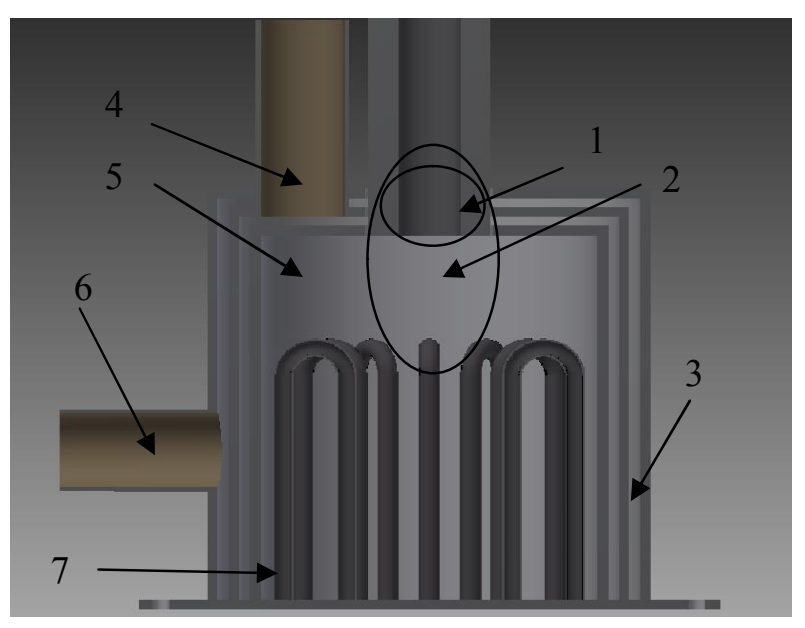

Fig. 4. The structure of designed combustion chamber for Stirling engine. 1. Ignition location; 2.Burner location; 3. Air preheating layer; 4. Emission exhaust; 5. Heat exchanger cavity; 6 . Fresh air inlet; 7 . Heat tubes.

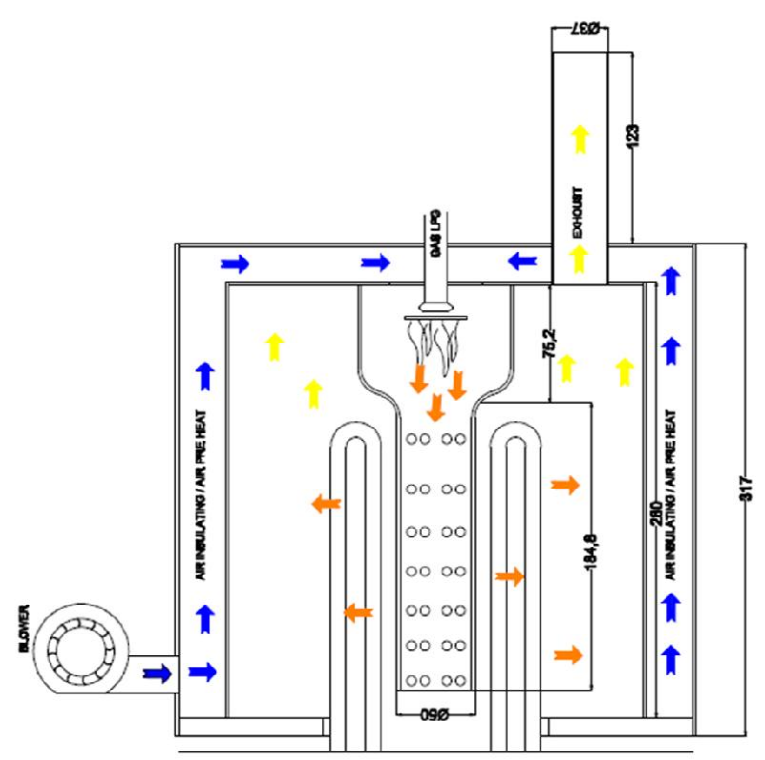

Fig. 5. Combustion shamber with preheat air and biogas fuel configuration

exchanger. The exhaust gas (yellow arrow) is then flowing through the outlet. The design allow for flameless combustion process to occur where higher heat rejection and lower fuel consumption has been reported with this process [20].

\section{Results and discussion}

Based on the design, the combustion chamber is then fabricated in our workshop and the result is depicted in Figure 6. The burner is made of stainless steel to allow for operating temperature upto $1000{ }^{\circ} \mathrm{C}$ and corrosion resistance properties. Since the biogas fuel is used directly without pre-treatment ir upgrading, the hydrogen sulphide and water content may cause excessive corrosion of both burner components as well as Stirling engine's heat exchanger. 


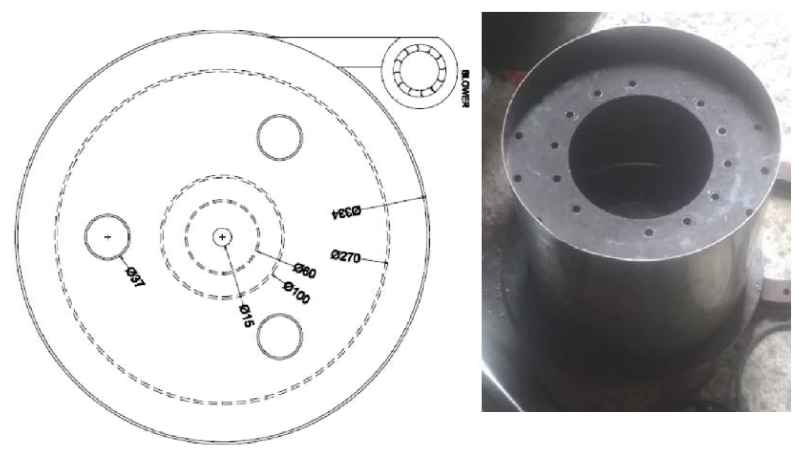

Fig. 6. Combustion chamber fabrication

The initial combustion process with ambient temperature air took about 10 minutes before the combustion chamber wall hot enough to heat up the air entering the chamber. After successive burning process with preheat air, the combustion showed less flame obtained, indicated a higher temperature combustion leading to lower fuel consumption. The burning process is depicted in Figure 7 below. At this condition, fuel consumption is reduced by $37 \%$ compared to initial burning process. The temperature of preheat air is 300 ${ }^{\circ} \mathrm{C}$. At the Stirling engine's heat exchanger, temperature of $600{ }^{\circ} \mathrm{C}$ is measured.

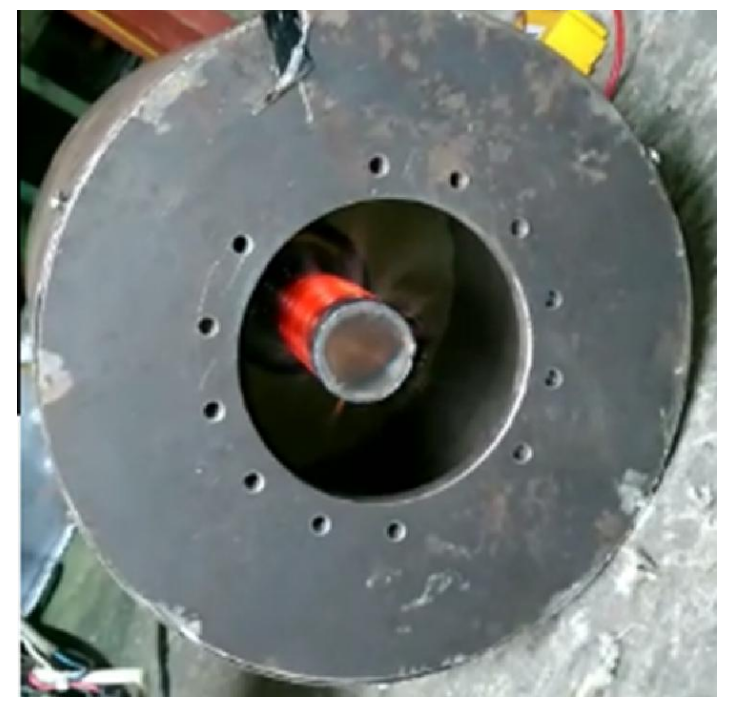

Fig. 7. Combustion after pre-heat air reaches $300{ }^{\circ} \mathrm{C}$

The complete power generation system with Stirling engine is shown in Figure 8. The required temperature of the Stirling engine is 600 to $1000{ }^{\circ} \mathrm{C}$. The components of the power generation system include the biodigester, Stirling engine, a blower, a burner, the combustion chamber, control system, AC power inverter, and a fuel pump. Included within the Stirling engine are the alternator, heater, cooler, nitrogen, and water-to-air radiator (heat exchanger). The blower supplies the mass flow rate of atmospheric air to the system with a minimal pressure increase. The air is then heated in the preheater using the hot exhaust gases coming from the engine.

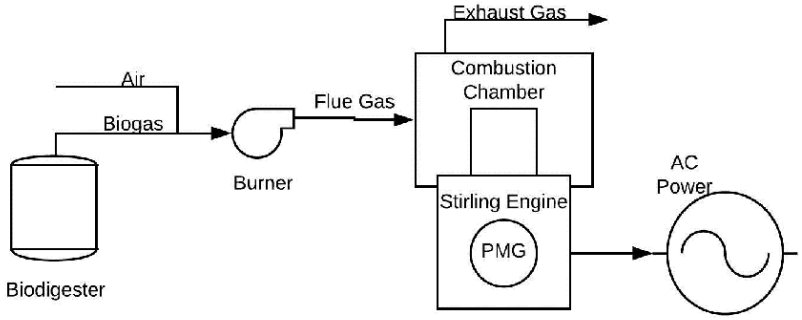

Fig. 8. Stirling engine system schematic diagram

Table 3. Calculation of power generation system capacity

\begin{tabular}{|c|c|c|c|}
\hline $\begin{array}{l}\text { Produced } \\
\text { Electricity }\end{array}$ & : & 5 & kW \\
\hline Operating Hours & : & 8 & Hours/Day \\
\hline Conversion & : & 243 & $\begin{array}{l}\text { kWh/tonnes biomass } \\
\text { (100\% organic) }\end{array}$ \\
\hline Feedstock & : & 0.165 & $\begin{array}{l}\text { tonnes/Day (if } 100 \% \\
\text { organic as the feedstock) }\end{array}$ \\
\hline $\begin{array}{l}\text { Volume Biogas } \\
\text { Reactor }\end{array}$ & $:$ & $\begin{array}{l}165 \\
120 \\
1975\end{array}$ & $\begin{array}{l}\mathrm{kg} / \text { Day (if } 100 \% \text { organic } \\
\text { as the feedstock) } \\
\mathrm{m}^{3} / \text { tonnes biomass } \\
\text { (100\% organic) } \\
\mathrm{m}^{3} \text { hiogas }\end{array}$ \\
\hline & & 19.75 & $\mathrm{~m}^{3}$ biogas \\
\hline
\end{tabular}

The combustor burns the fuel increasing the air and gas mixture temperature to its operating point.

The power capacity for the system is calculated and presented in Table 3 . For a $5 \mathrm{~kW}$ electrical power generation with 8 hours of operation daily, the required biogas to fuel the system is about $20 \mathrm{~m}^{3}$.

Based on the model proposed in [3] the calculation of the capacity and system efficiency are obtained from the total solid work required and methane gas produced as shown below:

$$
\begin{array}{r}
T S=27,7 \% \times Q \\
V S=74,1 \% \times T S \\
V B S=0,676 \times V S \\
V G M=60 \% \times V B S
\end{array}
$$

where :

Q : solid waste ( $\mathrm{kg} /$ Day)

TS : total solid ( $\mathrm{kg} /$ Day)

VS : volatile solid ( $\mathrm{kg} /$ Day)

VBS : volume biogas production $\left(\mathrm{m}^{3} /\right.$ Day)

VGM: methane production ( $\mathrm{m}^{3} /$ Day)

The capacity and efficiency of the power generation system is presented in Table 4 . The power generation efficiency of $36 \%$ is obtained with $3.86 \mathrm{~kW}$ power capacities along 12 hours of operation per day or equivalent to $128 \mathrm{kWh}$ per day. 
Table 4. Calculation of power generation system efficiency

\begin{tabular}{|llrl|}
\hline Q & $:$ & 165 & $\mathrm{~kg} /$ Day \\
TS & $:$ & 45.60 & $\mathrm{~kg} /$ Day \\
VS & $:$ & 33.79 & $\begin{array}{l}\mathrm{kg} / \text { Day } \\
\text { VBS }\end{array}$ \\
VGM & $:$ & 22.84 & $\begin{array}{l}\mathrm{b}^{3} \\
\mathrm{~m}^{3}\end{array}$ \\
& $:$ & 13.70 & $\begin{array}{l}\text { methane/Day } \\
\text { Produced Electricity }\end{array}$ \\
Installed Capacity & $:$ & 128.68 & $\mathrm{kWh} /$ Day \\
Running Capacity & $:$ & 10.72 & $\mathrm{~kW}$ \\
\hline
\end{tabular}

\section{Conclusion}

In this study a biogas-fuelled Stirling engine for electric power generation is designed and developed. The system utilizes a Gamma V2-6 Stirling engine. The engine has maximum capacity of $10 \mathrm{~kW}$. The required fuel input is $60,000 \mathrm{BTU} / \mathrm{hr}$ or equivalent to $17 \mathrm{~kW}$. The fuel is a biogas which comes from a biodigester. The system requires constant heat from the combustion chamber, hence a novel fuel distribution control is introduced. A specific burner is also designed to fulfil the purpose. The system has $5 \mathrm{~kW}$ electric power capacity fuelled by 165 $\mathrm{kg}$ /day solid waste (biowaste) from local farm. The biodigester needed is $20 \mathrm{~m}^{3}$. Based on empirical model, the estimated energy efficiency of the system is $36 \%$. In addition, the system offers potential utilization of hot water as by side product. The combustion temperature of the burner is in the range of 600 to $1000{ }^{\circ} \mathrm{C}$. The burner is able to provide for simultaneous air preheater for lower fuel consumption leading to $37 \%$ lower fuel consumption.

We express our gratitude to the Universitas Indonesia which has funded this research through the scheme of Hibah Publikasi Internasional Terindeks untuk Tugas Akhir Mahasiswa (PITTA) No.2382/UN2.R3.1/HKP.05.00/2018.

\section{References}

[1] Enerdata, Globa Energy Statistical Data Yearbook 2018. (2008)

[2] Environmental Protection Agency (EPA). EPA 430P-17-001. Washington DC (2017)

[3] McDonald, Ta; Achari, Gopal; Abiola, Abimbola. Journal of environmental engineering and science. 7, 4 (2008)

[4] Obernberger I, Carlsen H, Biedermann F. International nordic bioenergy conference (2003)

[5] Richard K. Shaltens. EASA. 22nd Intersociety Energy Conversion Engineering Conference, International Energy Conversion Engineering Conference (1987)
[6] I. Urieli, D.M. Berchowitz. Adam Hilger, Bristol (1984)

[7] Houda Hachem, Ramla Gheith, Fethi Aloui, Sassi Ben Nasrallah. Energy Conversion and Management. 171 (2018)

[8] Ukpai, P.A. and Nnabuchi, M.M. Advances in Applied Science Research, 3 (2012)

[9] C.H. Cheng, H.S. Yang. Appl Energy, 92 (2012)

[10] G. Walker, R. Fauvel, R. Gustafson, J. van Bentham. Refrigeration, 5 (2) (1982)

[11] S.C. Costa, H. Barrutia, J.A. Esnaola, M. Tutar. Energy Convers Manage, 67 (2013)

[12] C.-H. Cheng, Y.-J. Yu. Renew Energy, 36 (2011)

[13] Olumide Wesley Awe, Yaqian Zhao, Ange Nzihou, Doan Pham Minh, Nathalie Lyczko. Waste and Biomass Valorization. Volume 8, Issue 2, pp 267283 (2017)

[14]Eugene A. Avallone, Theodore Baumeister III, Ali M. Sadegh. McGraw-Hill 11 (2006)

[15] C.J. Mordaunt, W.C. Pierce. Fuel, 124, pp. 258-268. (2014)

[16] Seyed EhsanHosseini and Mazlan Abdul Wahid. Renewable and Sustainable Energy Reviews. Volume 40, December 2014, Pages 868-875 (2014)

[17] Y. Lafay, B. Taupin, G. Martins, G. Cabot, B. Renou, A. Boukhalfa. Exp Fluids, 43, pp. 395-410. (2007)

[18]I. Gökalp, E. Lebas. Appl Therm Eng, 24, pp. 16551663. (2004)

[19] S. Jahangirian, A. Engeda, I.S. Wichman. Energy Fuels, 23, pp. 5312-5321. (2009)

[20] Seyed Ehsan Hosseini, Ghobad Bagheri, Mazlan Abdul Wahid. Energy Conversion and Management. Volume 81, May 2014, Pages 41-50. (2014)

[21] R. Weber, A.L. Verlaan, S. Orsino, N. Lallemant. J Inst Energy, 72 (1999), pp. 77-83 